\title{
Sport as a Mean of Communication for Prisoners
}

\author{
By Blerina Gjerazi* \\ Rejnaldo Gjerazi $i^{\dagger}$
}

\begin{abstract}
Sports play a significant role in the social and cultural life of a country. Various empirical studies have provided important results on how sports affect the recognition, personality and wellbeing of particular individuals or groups. Moreover, the role of sports in delivering messages and communicating with various audiences should not be underestimated. In closed institutions, such as prisons, sports have been considered as useful means of communication and expression. In addition to a "Morse Code" used and adapted among prison populations, sports remain a second comprehensive tool of communication. Using communication and sports theories intertwined with empirical evidence, this study will investigate the factors that influence prisoners to get involved in sports activities, what they communicate through sports, and how sports influence the building of communication networks and personality development. Based on qualitative and quantitative data gathered in the 23 penitentiary institutions in Albania, this study suggests that sports play a significant role in enhancing relationships and communication between prisoners. The traits of prisoners revealed during their involvement in sports activities can help the institution to gather additional information about prisoners' personalities and behaviors.
\end{abstract}

Keywords: Communication, sport, prisoners, sports activities.

\section{Introduction}

Configuration and processes theory represents interesting views regarding structures and relationships, especially in cases of increasing or decreasing dependence on each other and the level of power. In fact, although this theory has not studied individuals or societies in isolation, but has analyzed social networking and interconnections, the circumstances of development and formation of human behavior can be examined by the categorization of social processes. However, these position self-confidence at the center of the relationship of social networking and, as a result, yields more power to some individuals than others. In this case we consider as a key variable, which can be studied even in isolated populations, individuals in prisons.

Analyzing the definition of Elia's (1990) configuration, as cited by Quintaneiro (2006) "a web of interdependences formed among human beings and which connects them, a structure of mutually oriented and dependent persons" are important representations of the power of communication between prisoners. Moreover, these can be revealed when the leading maxima is formed through sports activities.

Not without purpose, sports theories are a particular focus of study because they are closely related to the notion of power and the development of society. Although scholars or theorists in the field of sports provide various arguments about the role of sports in the culture and identity of an individual or group, no

\footnotetext{
${ }^{*}$ Head of Analysis and Statistics Department, General Directorate of Prisons, Albania.

${ }^{\dagger}$ Head of Trainers, Sport Club Tirana, Albania.
} 
one underestimates the role of sports in human relationships. Figurational theory conclusions about the role of sports are explained by Dunning (1999) "as a tool that controls violence and stress reduction" and have thus been listed by prison staff as major factors in organizing sports activities. In addition, the illustration by Dunning (1999) of the perspective on which interactionist theory focuses shows how sport is created and made meaningful by individuals. This will be the basis for the interpretation of quantitative data and implementation of this study.

Taking into consideration interactionist theory applications and the development of human relationships, the main goal of this paper is to investigate the role of sport activities in prison in enhancing verbal and non-verbal communication between prisoners. In particular, we examine how sport activities are used by prisoners to enhance relationships and communication. The shift here is that rather than a mechanism of resocialisation, it seems that sports imply other perspectives regarding prisoners. While the penitentiary institutions include sport activities as rehabilitation programs, the prisoners have their own "agenda" for the use of sports. This study aims to explore the differentiation between penitentiary institutions' agendas and prisoners' agendas for the use of sports, and more specifically, the way that sports have been personalized by prisoners and the significance of participating in sport activities. Dibra, a former director general of prisons in the 2012 annual meeting of prison directors stated, "we have failed in our work if we have not been able to understand why prisoners get involved in activities". It seems that understanding prisoners' behavior and whether their involvement in various activities may be purposeful is considered highly important for the prison service.

The data of the General Directorate of Prisons show that there is high number of prisoners participating in sports activities. According to March 2017 statistics, in a population of 5597 prisoners, 3141 prisoners participated in sports activities organized in all penitentiary institutions in Albania. ${ }^{2}$

\footnotetext{
${ }^{1}$ Gazment Dibra, Former Director General of Prisons 2008-2013

2 Data refer to the meeting on the $31^{\text {st }}$ of March 2017 of the General Directorate of Prisons. There are 23 penitentiary institutions in the Republic of Albania, including an institution for juveniles, an institution for elderly and disabled persons and a special health institution for prisoners. It should be noted that compared with other activities organized in the detention facilities, participation in sports activities comprises the highest number of prisoners. Referring to the data of March 2017, the total number of prisoners in educational and cultural social activities was 849 inmates. The number of inmates who have frequented the library was 227 , while the number of prisoners in literary and artistic activities was 309. Also, compared with the number of prisoners participating in professional and educational courses, as well as special rehabilitation programs, the number of prisoners in sports activities is many times higher. During March 2017, professional courses were attended by 195 prisoners, teaching process by 212 inmates, as well as special rehabilitation programs were followed about by 1200 prisoners.
} 
Table 1. Number of Sports Activities and of Prisoners Participating During 2016

\begin{tabular}{|l|c|c|}
\hline Month & No. of sport activities & No. of prisoners \\
\hline January & 2142 & 3500 \\
\hline February & 2350 & 3225 \\
\hline March & 2371 & 3231 \\
\hline April & 2330 & 3232 \\
\hline May & 2400 & 3311 \\
\hline June & 2390 & 3300 \\
\hline July & 2401 & 3180 \\
\hline August & 2410 & 3121 \\
\hline September & 2425 & 3150 \\
\hline October & 2418 & 3145 \\
\hline November & 2421 & 3158 \\
\hline December & 2486 & 3347 \\
\hline
\end{tabular}

Source: General Directorate of Prisons 2016.

As noted in the above table, there are considerable sports activities ${ }^{3}$ arranged with a significant number of prisoners participating. Compared with other activities organized in institutions, sports are the largest activity due to the high number of participants but also to the type of activities being provided. Consequently, the interaction and communication of prisoners with one another has not been studied merely within the context and constraints of the limited conditions of liberty, but also under specific circumstances by sticking to Elia's (1990) principle, as cited by Quintaneiro (2006), "not to analyze the actions of isolated individuals, but the links created between individuals and communities".

\section{Review of Literature}

\section{Involvement of Prisoners in Sports Activities}

Based on findings of various research as well as empirical data collected from five countries, Theeboom et al. (2012: 14) provide relevant approaches related to the involvement of prisoners in sports activities. The 5 most important factors are: 1) the general health of inmates; 2) normalization conditions; 3) improvement of the social contract; 4) meaningful leisure-time; and 5) legislation requirements. Other authors discuss additional factors of inclusion for prisoners in sports activities. Berit (2001: 4) argues "sport is a specific activity where the

\footnotetext{
${ }^{3}$ Sport programs in Albanian prisons have been developed after 2000, a period during which they were considered not only as a therapy through sport but also as an important tool for the rehabilitation of prisoners. The conditions for the development of sport activities are not optimal in all institutions, in particular related to sport conveniences. The most common sport disciplines in Albanian prisons are football, volleyball, basketball, fitness and aerobics, as well as table games. Sports championships take place between prisons, where the most famous is football and chess championship. Sports facilities can be used 2 times a day by inmates.
} 
aim is to express oneself physically. By the physical expression, the individuals show skills and patterns of movements that are given within historically and culturally defined norms and rules." The manifestation of prisoners as individuals and their demonstration of physical strength are important elements that can be considered to assess and analyze the characteristics and behavior of inmates. Duriçi, a psychologist at Ali Demi prison, explains "in particular during sport activities, the emergence of the physical potential of prisoners constitutes a special feature of communication but also of their personality." Moreover, as part of the institution's rehabilitation program, it affects the safeguarding of psychophysical conditions and promotes interaction and pro-social behavior. Being aware of the fact that sports activities are preferred among inmates compared to other programs, penitentiary institutions use these as a means for reducing recidivism in prisons. Albanian athletic trainer Karanxha confirms that sport education offers a golden opportunity to positively change an individual and increase self-esteem. Meek et al. (2012: 1) statements on sport "as a vehicle to achieve non-sport policy objectives" and the discussion that "the annual cost of reoffending is the same as the cost of hosting the 2012 Olympics" show evidenced-based practices for why prisoners should get involved in sport activities, as well as the reason why penitentiary institutions should invest in sport programs.

Chamberlain (2014: 56) discusses that sports "improve behavior, achievements, skills and attitudes of prisoners". Bruci, a psychologist at the high security Burrel prison, explains, "Participation of prisoners in sports activities is not just about implementing the regime and the rules of the institution, but is closely related to their identity and the way they communicate within the group." In a broader spectrum, when participating in sports activities, body language serves as a communication tool, which if placed into the interactionist perspective can lead to identity analysis and comprehensive connotation with factors of getting involved in sports.

Gallant et al. (2014), Meek et al. (2012), Meek et al. (2012) and other studies on the importance of developing sports activities in prisons have put emphasis on reducing anxiety and violent behavior, purposeful pastimes, social inclusion, but also as means to strengthen relationships.

This has been further reinforced by Thanasaj, a prison specialist, who says that "sports help to better understand the personality, behavior and communication of prisoners." Some educators in prisons would go further and insist that sports are central tools for the resocialisation of prisoners. Nevertheless, Carlton's (2015: 18) approach that "in our kind of society the deviant may be resocialised by means of some accepted reformative treatment" should be considered. A particularly interesting view has been given by Daly (1992: 396), who discusses the function of prisons as institutions "to realign the behavior of members who have in some way deviated from their expected roles".

Article 58 of the General Regulation of the Albanian Prisons stipulates that among various activities the process of education includes group treatment of prisoners through involvement in sports activities. In some penitentiary institutions criteria are set for participation in sports activities, and in some cases non- 
participation is part of disciplinary measures imposed on prisoners. "Every person should have a high level of compassion and good communication. A prisoner should not have disciplinary measures taken for physical violence against other prisoners, or antisocial or hostile behavior" - says Duriçi.

\section{The Impact of Sports in Building Communication Networks}

Various authors and sport theories have argued that sports in general promote social skills and enhance communication between individuals. Meek et al. (2012) observed that sports and physical activities can "contribute to improving relations not just among prisoners but also between prisoners and staff." Sabo (2001: 65) emphasized two main outcomes of involvement in sports. "First, sports provide prisoners with tools for self-expression and physical freedom. Secondly, prison staff knows that involvement in sports helps make inmates more tractable." Analyzing self-expression and physical freedom can lead to useful information associated with prisoners' personality, as well as whom they want to be with. Considering the increasing role of sports as means of communication between prisoners and an interconnected agenda, being together as a team seems to be a useful strategy for accomplishing their goals. Because of the prison context, sports activities encourage group gatherings and exchanges. Fakaj confirms that it has been realized that "sports are becoming very fast a useful tool for prisoners to socialize and create same group of interest".

Nonverbal communication, signs and symbols are among the most tracked behaviors by prison staff. Sufaj claimed that specific training modules have been drafted for the prison staff specializing in communication and how sports activities serve in building networks. The outcomes of networks of communication between prisoners cannot be generalized as negative, yet they are supposed to be under continuous monitoring.

\section{Communicating Through Participation in Sports Activities}

Communication of prisoners with each other comprises a basic element of the prison system to understand and analyze how a prisoner behaves on a daily basis. Behavioral characteristics become even more evident in cases of group interaction. As noted above, football is the most preferred sport among male prison populations, while for females volleyball is most preferred. ${ }^{4}$ As activities that take place in groups and under the pressure of game rules, institution norms and the personal desire to win, the participants' features are displayed. Not without purpose, prison staff monitors prisoners during sports because as Bogadani mentioned "through sports they can identify how impulsive or aggressive an individual is and how they communicate."

Vandebosch (2004: 209) brings forward an evidenced-based observation relating to participation in collective activities. Based on the findings of her study, "stronger feelings of insecurity went along with lower importance scores

${ }^{4}$ Based on February 2017 data in the Albanian prison system are 5458 male prisoners and 100 females. 
given to (potentially dangerous) collective prison activities, such as doing sports and walking in the prison yards" have been revealed. This can lead to additional analysis regarding the use of sports among the prison population and more specific about communication.

\section{Methodology}

Analyzing sports in the perspective of communication and dissemination of messages in the community of prisoners is a new observable fact in the field of sports studies in prisons, as well as the field of communication. The methodology applied in this paper is based on quantitative and qualitative data collection. Implementation of this methodology aimed at obtaining "generalizability" as defined by Silverman and Marvasti (2008: 377). These authors in their book "Doing Qualitative Research: A Comprehensive Guide" have identified four ways of obtaining generalizability, one of which is "combining qualitative research with quantitative measures".

Qualitative interviews were conducted with heads of social care sectors and psychologists in 23 penitentiary institutions in Albania. Quantitative data were gathered through questionnaires with open and closed questions from the prison staff responsible for monitoring and evaluating the behavior of detainees on a daily basis. The questionnaire consisted of 24 key questions, aiming at gathering information about the impact of sports on the behavior of prisoners and exploring the motives of prisoners for getting involved in sport activities.

Also, 213 questionnaires were filled out by prisoners selected randomly by the prison service, aiming at providing an analytic observation and critical assessment between facts listed by the staff and the prisoners related to participation in sport activities. Prisoners were selected from the group of inmates that have been involved in sport activities. The techniques used most in this paper for collecting, administering, analyzing and processing data were: structured questionnaires with closed questions for prisoners; structured questionnaires with open questions for heads of social sectors and psychologists; and semi-structured questionnaires with prison staff responsible for monitoring and evaluating behavior of detainees. Table 2 indicates the number of persons interviewed within each type.

Table 2. Number of Persons interviewed and the Type of Interview

\begin{tabular}{|l|c|l|}
\hline \multicolumn{1}{|c|}{ Interviewees } & $\begin{array}{c}\text { Number of } \\
\text { persons }\end{array}$ & \multicolumn{1}{|c|}{ Type of interview } \\
\hline $\begin{array}{l}\text { Head of social care sectors and } \\
\text { psychologists }\end{array}$ & 23 & $\begin{array}{l}\text { Structured questionnaires with } \\
\text { open questions }\end{array}$ \\
\hline $\begin{array}{l}\text { Prison staff responsible for } \\
\text { monitoring and evaluating behavior } \\
\text { of detainees }\end{array}$ & 23 & $\begin{array}{l}\text { Semi structured questionnaires } \\
\text { with open and closed } \\
\text { questions }\end{array}$ \\
\hline Prisoners & 213 & $\begin{array}{l}\text { Structured questionnaires with } \\
\text { closed questions }\end{array}$ \\
\hline
\end{tabular}


The selection of this case study helps us to investigate and understand the factors influencing prisoners' involvement in these activities. Early research indicates that interviewing prisoners can lead to discovering "many factors of sociological significance, such as self conception, levels of aspiration, attitudes and motives of offenders" (Newman 1958: 127). Also, Newman (1958: 127) emphasized the "necessity of personnel cooperation". In this regard, specific questionnaires were drafted for social, psychological and education staff in prisons.

In addition, official statistics of the General Directorate of Prisons, contemporary communication, sports, relationship theories and other studies in this field comprise the significant orientation of this paper.

The empirical data have influenced the development of the hypothesis of this paper that suggests that sports play a significant role in enhancing relationships and communication of prisoners. The traits of prisoners revealed during their involvement in sports activities can help the institution to gather additional information about prisoners' personalities and behavior.

\section{Results}

Regarding the situation in the Albanian prison system, data collected show interesting facts about the reasons motivating prisoners to participate in sports activities. As indicated in Table 3,31\% of the prisoners who engaged in sport activities participate as part of a rehabilitation and activities program of their penitentiary institution. $26 \%$ of prisoners use sports as entertainment while in prison. $17 \%$ of prisoners mentioned the improvement of health conditions, $13 \%$ the reduction of stress, $9 \%$ the promotion of good behavior, and $4 \%$ just as a way to get out of the cell.

Table 3. Factors Motivating Prisoners to Participate in Sport Activities

\begin{tabular}{|l|c|}
\hline Variable & $\mathbf{\%}$ \\
\hline Part of rehabilitation program of the penitentiary institutions & 31 \\
\hline Entertainment program & 26 \\
\hline Improvement of health conditions & 17 \\
\hline Stress reduction & 13 \\
\hline Promotion of good behavior & 9 \\
\hline A way to get out of cell & 4 \\
\hline
\end{tabular}

Compared to Theeboom et al. (2012), our findings observed that the range of motivation to participate in sports activities of the Albanian prisoners is approximately the same, but with some distinctions found in the ranking of the listed factors. It must be emphasized that a proportion of prisoners $(9 \%)$ use sports activities to promote good behavior. This is an important feature that provides direct analysis of how prisoners use sports on a daily basis to communicate nonverbally with the staff and among themselves.

Data collected show that sports serve as a tool for building communication networks. Through participation in sport activities, mini-communities can be 
created within prison estates that are influenced also by the type of sport. As shown in Table 4, 60\% of the prisoners selected the inmates of their sport group themselves, and in the other cases it was the institution that decided. Even though in a low number of cases the institution divided the groups, it resulted in conflict between prisoners, which has served to imply risk assessment for that purpose.

Table 4. Selection of Sport Group in Prisons

\begin{tabular}{|l|c|}
\hline Variable & \% \\
\hline The prisoners select the group by themselves & 60 \\
\hline Penitentiary institutions decisions & 38 \\
\hline No answer & 2 \\
\hline
\end{tabular}

When asked if sports have been used to enhance relationships or communication, $44 \%$ of prisoners selected sport as the most important tool for both factors, while $33 \%$ of prisoners answered just relationships, $18 \%$ just communication, and the rest selected none of them.

Table 5. Influence of Sports in Enhancing Communication and Relationships

\begin{tabular}{|l|c|}
\hline Variable & $\mathbf{\%}$ \\
\hline Both of them, communication and relationships & 44 \\
\hline Just relationships & 33 \\
\hline Just communication & 18 \\
\hline None of them & 5 \\
\hline
\end{tabular}

It was interesting to find that when asked specifically if sports have been used to expand communication networks within prisons, $38 \%$ of the interviewees answered yes, $26 \%$ to some extent, and the others preferred not to answer.

Table 6. Influence of Sports in Expanding Communication Networks in Prisons

\begin{tabular}{|l|c|c|c|}
\hline Variable & $\begin{array}{c}\text { Yes } \\
(\boldsymbol{\%})\end{array}$ & $\begin{array}{c}\text { To some } \\
\text { extent } \\
(\boldsymbol{\%})\end{array}$ & $\begin{array}{c}\text { No answer } \\
(\mathbf{\%})\end{array}$ \\
\hline $\begin{array}{l}\text { Have sports influenced in expanding } \\
\text { communication networks among each other }\end{array}$ & 38 & 26 & 36 \\
\hline
\end{tabular}

Duriçi explained that if prisoners decide to not answer a specific question this must be related to the "security of information" by prisoners. Thus, they may assess that this information must be kept secure from others and used for their purposes.

What do Albanian prisoners communicate while doing sports? As shown in Table 7 below, 11 main characteristics were disclosed by prisoners while participating in sport activities: 1) Power, 2) Leadership, 3) Self-confidence, 4) Obedience to the rules, 5) Humbleness, 6) Tolerance, 7) Patience, 8) Talent, 9) Aggressiveness, 10) Self-control, and 11) the need to be noticed. Observing the results, data show only slight distinction between each characteristic, so it is slightly difficult to distinguish which of them dominates. Self-confidence, self- 
control and talent can be defined as the three foremost nonverbal communication traits revealed during sports activities (11\% each). The second group of traits is leadership, the need to be noticed, and obedience to the rules $(10 \%$ each). Tolerance and patience comprise $9 \%$ of answers for each. The last three traits that received lower scores are aggressiveness $8 \%$, power $6 \%$ and humbleness $5 \%$.

Table 7. Communication of Prisoners through Sports

\begin{tabular}{|l|c|}
\hline Variable & \% \\
\hline Power & 6 \\
\hline Leadership & 10 \\
\hline Self confidence & 11 \\
\hline Obedience to the rules & 10 \\
\hline Humbleness & 5 \\
\hline Tolerance & 9 \\
\hline Patience & 9 \\
\hline Talent & 11 \\
\hline Aggressiveness & 8 \\
\hline Self-control & 11 \\
\hline Need to get noticed & 10 \\
\hline
\end{tabular}

It must be underlined that prisoners who have answered "power" are accommodated in high security institutions, which shows that in these prisons the prisoners tend to display as a primary characteristic of communication the power of the group in the selection of the group that will take part in the game, and also in assigning roles, schedule of attendance, as well as the opponent team.

If performing a data categorization based on the terminology of each variable, three communication lines through sports can be identified:

The first line, which includes self-confidence, self-control and talent, can be categorized as communication of personal attributes. These patterns are jointly developed and dependent on individual traits and characteristics composed with the uniting power of communication. Taking into consideration Foucault's (1978: 93) definition of power in a prison setting where "it is the name that one attributes to a complex strategic situation in a particular society, not the institution," it can be realized why personal attributes serve as an actual tool of communication. In addition, these attributes induce prisoner's capacities and credentials.

The second line, which includes leadership, need to get noticed, and obedience to the rules, can be categorized as communication of attention attributes. In practice, this can be seen as a combination of individual traits and rules imposed by institutions. This association is not casual. The General Regulation of Prisons approved by the Decision of the Council of Ministers No. 437, dated 20.05.2015, has foreseen particular articles regarding the involvement of prisoners in activities. The prisoners are aware and have substantial information about what they want to show off. Evaluating their individual characteristics and understating how to play the "game" in a prison 
context can lead to a continuing process towards group competence and control. In addition, these attributes induce prisoner's "existence" and identification.

The third line, which includes tolerance and patience, aggressiveness, power and humbleness, can be categorized as communication of acceptance attributes. These acknowledge the norms to abide by and, in terms of institutional aspects, the issues to tackle, promoting positive behaviors and reducing negative ones. Special programs are organized within institutions for the promotion of good behavior, controlling aggressiveness and over-reacting. Tafa explains that during involvement in sports it is the best moment of taking into deep analysis the personality and trait of each prisoner, because it is a highly likely that they can "reveal their consciousness". This line of communication is also developmental to the extent that they classify prisoners in terms of their power of communication and with forms of communication.

\section{Discussion and Conclusion}

The law regulating the functioning of the Albanian Prison System such as law no. 8328 "For the treatment of detainees," dated 16.04.1998, and the General Regulation of Prisons have foreseen specific articles for the inclusion of prisoners in sport activities. As noted in monitoring reports, as well as statistical information of the General Directorate of Prisons, it seems that sports comprise the main group activity for the prisoners and with a considerable number of prisoners involved. In a population of 5597 prisoners, out of which 107 were females, it seems that approximately $56 \%$ of prisoners participate in sport activities. Even though the sports program in prisons started in 2000, there is no specific budget for this program and some institutions lack facilities for the implementation of the sport program. In general, prisoners can use sport facilities three times a day. For the implementation of sports program a low number of penitentiary institutions collaborate with sport clubs and athletic trainers. It should be emphasized that the education sectors in prisons have the lead for the organization of such activities. The most common sport disciplines in Albanian prisons are football, volleyball, basketball, fitness and aerobics, as well as table games and it seems that all prisoners have been given the opportunity to participate in such activities. As stated by prison educator staff, it should be mentioned that good behavior and conduct are prerequisites for involvement of prisoners in sports activities.

Social staffs in prisons assert that the majority of the prisoners engage in sport activities as part of rehabilitation program as well as leisure program. In general, $98 \%$ of the interviewees declared that sports have had no negative impact on the prisoners. It seems that the penitentiary institutions use sport as a tool for rehabilitation, while data in this study show that prisoners use it to enhance their relationships and communication within prisons. In this context, prison staff should recognize the fact that sports in prisons, despite serving as rehabilitative instruments, can have other inputs and thus be used as a significant tool to analyze prisoner behavior and nonverbal communication. As many prison 
practitioners have argued, involvement in sports activities can assist in knowing more about the personality of a prisoner and track their behavior.

This study has showed that there is a number of characteristics revealed by prisoners while participating in sports activities, such as power, leadership, self confidence, obedience to the rules, humbleness, tolerance, patience, talent, level of aggressiveness and self-control, along with need to get noticed. As a result, there is a need to explore the development of appropriate tools to systematically monitor and evaluate communication of prisoners during sport activities and also to develop strategic policy plan related to the use of sports as a mean of communication. Time spent in prison stipulates agenda setting, which means prisoners might have another agenda far beyond from that of the penitentiary institution. In this case, specifically in group gatherings or various activities implementation of methodical observing and assessment tools as an essential part of the programs prioritizing elements of communication must be an indispensable aim.

Referring to Foucault (1977: 256) definition of prisons "as disciplinary apparatus" penitentiary institutions should take into consideration the implementation of various strategies for the rehabilitation of those serving sentences and abiding to rules and regulation of penitentiary institutions. Scholars and researchers evidenced the role of sports in prison as psychosocial tool for inmates, rehabilitative instrument, an important contributor to wellbeing and mental health, empowering relations and communications. Stimulation of positive involvement of inmates in sport activities prioritizing positive behavior and reducing aggressiveness has been an ongoing effort. These efforts are advised to be equivalent with raising professional abilities of the staff and development of education curricula regarding the use of sports as a mean of communication and development in a prison setting.

\section{Acknowledgments}

Our thanks to former Director General of Prisons Mr. Miklovan Kopani for the professional support for the implementation of this study into prisons. Also, dedicated thanks to the social staff of the penitentiary institutions and persons deprived of their liberty involved in this study. We hope that this study will be useful in their daily work and wider.

\section{References}

Berit J (2001) Sport, Masculinities and Power relations in Prison, 4. The Norwegian University of Sport and Physical Education. Retrieved from at https://brage.bib sys.no. [Accessed 10 December 2016].

Carlton E (2015) Ideology and Social Order, 18. Social Theory Volume 32. New York: Routledge Library Editions.

Chamberlain MJ (2014) Sports-based intervention and the problem of youth reoffending: a diverse enough tool for a diverse society? In K Dashper et al. (eds) Diversity, 
Equity and Inclusion in Sport and Leisure, 56. London and New York: Taylor and Fracis.

Daly JK (1992) Toward a formal theory of interactive resocialization: the case of adoptive parenthood. Qualitative Sociology 15(4): 396. Ontario, Canada: Human Sciences Press Inc. N1G 2W1.

Dunning E (1999) Sport matters, sociological studies of sport, violence and civilization. 13. Routledge. USA and Canada.

Foucault M (1978) The history of sexuality, vol. 1. New York: Random House.

Foucault M (1977) Discipline and punishment: The birth of the prison. New York: Vintage.

Gallant D et al (2014) Recreation or rehabilitation? Managing sport for development programs with prison populations. Sport Management Review. http://dx.doi.org/ 10.1016/j.smr.2014.07.005.

General Regulation of Prisons. Approved by the Decision of the Council of Ministers No. 437 dated 20.05.2015

General Directorate of Prisons Statistics. Retrieved from www.dpbsh.gov.al. [Accessed 15 April 2017]. (In Albanian)

Meek R, Champion N, Klier S (2012) Fit for release: how sports-based learning can help prisoners engage in education, gain employment and desist from crime. London: Prisoners Education Trust

Meek R (2013) Sport in Prison: Exploring the Role of Physical Activity in Correctional Settings. Routledge.

Newman JD (1958) Research interviewing in prison. Journal of Criminal Law and Criminology 49(2).

Quintaneiro T (2006) The concept of figuration or configuration in Norbert Elias' sociological theory. Teor. Soc. 2 Retrieved from http://socialsciences.scielo.org/ pdf. [Accessed 12 January 2017].

Sabo D (2001) Doing time, doing masculinity: Sports and prison. In DF Sabo, TA Kupers (eds) Prison masculinities. London and Philadelphia. WJ University Press.

Silverman D, Marvasti A (2008) Doing Qualitative Research: A Comprehensive Guide. USA: Sage Publications.

Theeboom M et al (2012) Move into sport, move through sport! Retrieved from http:// www.prisonersonthemove.eu/. [Accessed 20 October 2016].

Vandebosch H (2004) Media use as an adaption or coping tool in prison. In K. Renckstorf et al (eds) Action Theory and Communication Research. Recent Development in Europe. Berlin.

\section{Personal Interviews}

Bruci, Sokol. Psychologist. Burrel Prison. [23.12.2016]

Bogadani, Ysni. Head of Social Sector. Fier Prison. [29.12.2016]

Duriçi, Blerina. Head of Social Care Sector. Ali Demi Prison. Tirana. [15.12.2016]

Fakaj, Fako. Head of Social Service. Vlora Prison. [13.12.2016]

Karanxha, Liliana. Athletic Trainer. Sport Club Tirana. [13.11.2016]

Sufaj, Femi. Head of Training Sector. General Directorate of Prisons. [20.11.2016]

Tafa, Indrit. Head of Social Service. Lushnja Prison. [28.12.2016]

Thanasaj, Redona. Psychologist. Jordan Misja Prison,Tirana. [15.12.2016] 